IRA-International Journal of Education \&

Multidisciplinary Studies

ISSN 2455-2526; Vol.17, Issue O1 (Q1, 2021)

Pg. no. 8-17.

IRA Academico Research

\title{
Subaltern Writing in Hag-Seed
}

\section{Meijiao ZHAO}

University of Science and Technology, Beijing, China.

Type of Work: Peer Reviewed.

DOI: 10.21013/jems.v17.n1.p2

DOI URL: https://dx.doi.org/10.21013/jems.v17.n1.p2

ZHAO, M. (2021). Subaltern Writing in Hag-Seed. IRA-International Journal of Education \& Multidisciplinary Studies (ISSN 2455-2526), 17(1), 8-17. DOI: https://dx.doi.org/10.21013/jems.v17.n1.p2

(C) IRA Academico Research.

(c) $\mathrm{B}$ - The 4.0 International License subject to a proper citation to the publication source of the work.

Disclaimer: The scholarly papers as reviewed and published by IRA Academico Research are the views and opinions of their respective authors and are not the views or opinions of IRA Academico Research. IRA Academico Research disclaims of any harm or loss caused due to the published content to any party.

IRA Academico Research is an institutional publisher member of Publishers International Linking Association Inc. (PILA-CrossRef), USA. IRA Academico Research is an institutional signatory to the Budapest Open Access Initiative. Hungary advocating the open-access of scientific and scholarly knowledge. IRA Academico Research is a registered content provider under Open Access Initiative Protocol for Metadata Harvesting (OAl-PMH).

The journal is indexed \& included in WorldCat Discovery Service (USA), CrossRef Metadata Search (USA), WorldCat (USA), OCLC (USA), Open J-Gate (India), EZB (Germany) Scilit (Switzerland), Airiti (China), Bielefeld Academic Search Engine (BASE) of Bielefeld University, Germany, PKP Index of Simon Fraser University, Canada. 


\section{ABSTRACT}

Hag-Seed is a re-imagining story of Shakespeare's 'The Tempest' written by Margaret Atwood, a famous Canadian writer. Hag-seed is a successful adaptation in The Hogarth Shakespeare Project organized by Hogarth Press. In this novel, Atwood adopts the form "play in play" to recur the whole scene of The Tempest. Through the depictions of minor characters in a prison, the novel presents the dilemma and struggle of marginalized protagonists in front of the power. In the novel, the play directed by Felix criticizes the power abuse and the social oppression suffered by the lower classes and women. Atwood's rewriting of The Tempest aims to reveal the loss of the humanistic concerns in modern society and advocate making "the other" acquire their rights to free speech.

Keywords: Hag-Seed; The Tempest; power; subaltern; women

\section{Introduction}

\section{Margaret Atwood and Hag-Seed}

Margaret Atwood(1939-) is a prolific writer in Canada, producing over sixty books including novels, short fiction collections, poetry collections, children's books, non-fiction, and other works. She has the title of "the Queen of Canadian literature".

Hag-Seed was published in 2016 as a part of The Hogarth Shakespeare Project in memory of the $400^{\text {th }}$ anniversary of William Shakespeare's death. Atwood re-imagined The Tempest and created the modern version. After publishing, the novel has been widely praised by foreign media as "A marvel of gorgeous yet economical prose, in the service of a story that's utterly heartbreaking yet pierced by humor." "Laura Collins-Hughes, a famous critic of The Boston Globe, claimed that: What makes the book thrilling, and hugely pleasurable, is how closely Atwood hews to Shakespeare even as she casts her potent charms. 'Hag-Seed' is a most delicate monster----and that's delicate' in the 17th-century sense. It's delightful". ${ }^{2}$ Atwood has developed a long-standing interest in The Tempest, she claimed that: "It's an exciting challenge to rewrite it". ${ }^{3}$ She analyzed main characters in Shakespeare's play and put them in the modern context in a fresh way. In Hag-Seed, Atwood expresses her humanistic ideas to undertake her social responsibilities as a writer conveying the original themes of The Tempest.

The story Hag-Seed happens in a prison called Fletcher Country Correctional Institute. The protagonist Felix Phillips is an artistic director in a big theater, who experiences a tough time after losing his wife and daughter and being betrayed by his assistant Tony. He lives in a secluded shanty and becomes a teacher to teach the crimes literature in a prison nine years later. There, he decides to get The Tempest back and wants to revenge against Tony. He shows the play in play and gets a successful vengeance to the indifferent power and evil people. What is most impressive is not the successful vengeance but the forgiveness and the social problems it reveals. Atwood aims to make oppressed people acquire the dignity of existence and kindness from people in society by rewriting Shakespeare's The Tempest. 


\section{Literature Review}

Shakespeare's The Tempest is a story of an exiled ruler who uses magic to restore his daughter to power. It was performed in 1611 firstly and the play explores the consequences of European settlement in the New World. It is considered the most technical play among his works so The Tempest is widely adopted by a lot of playwrights and scholars. Some of them still keep the main focus on the same theme. William Davenant, who is claimed as Shakespeare's godson, performed his play The Enchanted Island, the adaptation of The Tempest with John Dryden in 1667. Davenant and Dryden keep a great deal of Shakespeare's verse, but remove much of the "mythic resonance" of the original, and add a fair amount of their invention. Some of them write a new story about one of the characters in The Tempest, like Caliban. The British poet Robert Browning published a poem "Caliban upon Setebos", which deals with Caliban and his reflections on Setebos, the brutal god he believes in. It was published in 1864, which was a time of chaos as Darwin has just presented the theory of evolution. People were confused as their beliefs about their existence were being challenged. Browning has resonated the same theological questions through his poem. In 1994, W.H. Auden completed his work The Sea and the Mirror. It is not merely a great poem but ranks as one of the most profound interpretations of Shakespeare's final play in the twentieth century. According to Auden, it is "really about the Christian conception of art" and it is "my Ars Poetica, in the same way, I believe The Tempest to be Shakespeare's." Besides, the play was adapted into different kinds of movies. In 1956, Fred Wilcox directed the movie Forbidden Planet, a science fiction film. The characters and isolated setting have been compared to those in William Shakespeare's The Tempest, and the plot also contains certain analogues to the play. In 1991, Peter Greenaway wrote and directed a movie called Prospero's Books, retelling the story of The Tempest. The books, their typography, calligraphy, and illustrations, are photographed in voluptuous detail. As Gielgud takes center screen in a narrative adapted from Shakespeare, Greenaway overlays those basic images of Prospero with a series of transparencies. The classical play was replayed again and again and Hag-Seed belongs to one of the excellent adaptations among those works and gained praise from most of the scholars.

As for the research on the novel Hag-Seed, it is still in the developing stage in recent years. Except for some book reviews, many scholars have discussed this work. Nishevita Jayendran explores the politics of creativity as moderated within and through the discourse of space, and its implications for freedom by considering the interpretations generated by the prisoners and the novelistic discourse in Hag-Seed(2016). The critic Dana Percec points out that the new version of The Tempest satisfies the contemporary audiences' taste through Atwood's convergent and divergent adaptation, who keeps her usual style but gives up the dystopia theme. He talks about the peculiarities of the rewriting of the play by Margaret Atwood in his essay: "The Canadian Tempest Margaret Atwood and Shakespeare Retold as Hag-Seed"(2018). In the article "True Trash: Genre Fiction Revisited In Margaret Atwood's Stone Mattress, The Heart Goes Last, And Hag-Seed“ (2017) Coral Howells discusses that Atwood has shifted the emphases in her storytelling, challenging realist conventions as she revisits an array of popular genres, constructing what we might describe as transgressive entertainments. As a retelling story, he argues that Hag-Seed is mixed with various elements, such as prison, digital figuration, and fantasy, which is different from other genre fiction. He also emphasizes that Atwood's works are always set in the cultural patterns of society, exposing "the dangers of fantasy thinking from romance to the dreams of science"(p.313) in Hag-Seed. Besides, in the article "The play is a prison: the discourse of Prison 
Shakespeare"(2018) written by Sophie Ward and Roy Connolly, they talked about the image of "prison" and the value of Hag-Seed. On the one hand, the crimes in the novel defeat the ruling people with their production of The Tempest, which reflects the function of Shakespearean drama against the powerful class. On the other hand, the crimes in the play use kinds of ways to revolts against the bourgeois power, like kidnapping, drink-spiking, and assault. So that Shakespearean drama gives people inspiration about vengeance and it can be a weapon to fight against the powerful class. Therefore, Atwood strongly cautions against mistaking fiction for fact, fantasy for reality because Shakespeare's text is itself a prison.

Moreover, there are some essays that discuss the Chinese version of Hag-Seed. Yuan Xia interpreted some classical images in The Tempest, like the magic used by Prospero and fairies, and the prison in the play. She discussed the connotative meanings implied in Hag-Seed in her paper "On Margret Atwood's Humanistic Ideas in Hag-Seed"(2017). Besides, Wang Qian argues that Atwood shaped various characters with their traumatic experiences, she posed power abuse, racial oppression, gender discrimination to make the inmates suffer from the trauma in her paper "Trauma Writing in Margaret Atwood's Hag-Seed"(2019). Wang thinks that in Hag-Seed, by describing the oppression inmates suffered from the ruling class, Atwood conveys her humanistic ideas to undertake her social obligations as a writer through inheriting the revenge and forgiveness theme of The Tempest. The research on Hag-Seed is still on the rise and there are emerging research achievements achieved by domestic and foreign scholars.

\section{Subaltern in Hag-Seed}

\section{'Calibans' in prison}

The sentence "Set me free" inspires Atwood to rewrite The Tempest. So she decided to set the novel's background in a prison. Prisons have been central to her novels, such as in The Handmaid's Tale, Alias Grace and The Heart Goes Last. In the original play, she found there are a lot of prisons and imprisonments and every one of the characters is constrained at some point. In Hag-Seed, the protagonist Felix teaches the literary class to the inmates and plays them in prison with the help of prisoners.

These inmates have a wide age from nineteen to forty-five with different criminal backgrounds. They are a group of marginalized people who can not act like ordinary people. They have bad impressions on ordinary people's minds so it is very hard for people to understand their deep sorrow and loneliness. They are oppressed and ignored by institutions and sometimes, their true selves were covered by their brutal appearances. Atwood described that: "For them, depression is never far. Push them too much and they'll collapse. They will give up, even the key players"( p.225). Actually, Atwood wants to present that prisoner's characters are not so evil as the murder or rape, they are a group of people who should be given more kindness.

Shakespeare's Caliban has long been an allegory for oppressed people. He is usually seen as a monster and portrayed on the stage as something less than human. He is dangerous and untrustworthy. He is undisciplined and it is impossible to discipline him, he can not be reasoned with and it is a state of perpetual rebellion. Therefore, he has to be disciplined by force and be controlled by Prospero. Whenever Caliban begins to look dangerous the most powerful magician Prospero will cause crippling pains 
throughout his body to stop him. Caliban in The Tempest is a hag-seed, the son of the witch of dead Sycorax. The title of Margaret Atwood's rewriting of The Tempest is "Hag-Seed". It obviously refers to Caliban and the contrapuntal reading would be to place Caliban's subjugation at its center, but Atwood didn't focus on the subaltern voice of the monster servant. She didn't follow the mainstream analysis on Caliban but expressed Caliban's voice more indirectly through the inmates that Felix teaches. Caliban doesn't take center stage, as the title suggests, although he is heard in the inmates' awareness that they all possess something of Caliban:

I'm getting all set to go on a ram-page!

Ain't gonna work for less than minimum wage----

Live in a shack and piss in a pail,

You earn yourself money by putting me in jail!

…...

Now Hag-Seed's black and Hag-Seed's brown,

Hag-Seed's red, don't care if you frown,

Hag-Seed's yellow and Hag-Seed's trash white,

He goes by a lotta names, he's roamin' in the night,

You treated him bad, now he's a sackful of fright.

Hag-Seed!(p.392)

The prisoners in Fletcher Correctional Prison are limited in this prison and their activities were controlled by the authorities. They don't have the freedom or rights to do what they want. Also, they hate the institutions like Caliban's hatred of Prospero.

From the modern perspective, in Atwood's novel, prisoners in prison are in a worse situation. They lack a sense of belonging in communities where they can build a meaningful connection with the world. In some cases, traditional prison management brings about much discrimination against the prisoners, like some of them, are sentenced more harshly than they should be. In the view of the powerful class, prisoners are "bottom-feeding social misfits"(Atwood, 2016,p.299). Nobody has hope for them and although they were released from prison, they will meet more and more rejections and difficulties in the world. Prisoners as the oppressed class, are vulnerable and unaccepted by ordinary people. Atwood presents the victims in prison in the hope that the public will pay more attention to the marginalized people.

\section{Women in the modern world}

Female characters are playing important roles in the plot development in Hag-Seed. The main female characters in this novel are Miranda, Estelle, and Anne-Marie Greenland. Miranda is Felix's daughter but she was dead when she was three because of a high fever, meningitis. But in the latter plot, as a spirit, she companies with Felix all the time. Estelle is a new character that Atwood created in this novel. Anne-Marie Greenland is an actress in Felix's play. Although the female characters in the modern novel are different from the female characters in The Tempest, they also suffer the oppression given by modern society. 
Anne-Marie, started as a child actress and moved on to ballet, and eventually got a shabby job at a cafe. She was the "Miranda" in Felix's The Tempest, she could have become famous because of the play. Playing Miranda would have done wonders for her because Felix could have brought out her talent, he could have taught her so much. It would have made her career. However, Felix was unceremoniously ousted from his role as Artistic Director of the Makeshiweg Festival, The Tempest was canceled. Her career also has been seriously damaged by Tony and Sal. And then she had "hard times in the world". She had crossed over completely into dance, but later, due to an injury, she had to leave before the company's spectacular The Tempest Replica and disappeared from her CV for eight months. She has to work hard to earn herself a living. She is an infamous dancer and struggles for living in society. Nowadays, society has a high standard of women. Like Estelle, she is a well-connected professor and pioneer of the Literacy Through Literature program. She is a stylish and vivacious woman. From the perspective of modern opinion, she is a successful woman and has her ability to decide everything. So compared to Anne-Marie, she has higher social status and has a voice in society.

The female character is put in a lower class in Shakespeare's The Tempest while Atwood as a feminist, made some differences in her novel. Although Anne-Marie suffers from the injustice patriarchal society, Atwood wants to build more independent female images for readers to know woman's power in society.

\section{The Rewriting of Power in Hag-Seed}

Hag-seed rewrites the power between Prospero and Caliban. In The Tempest, Caliban as the native people was oppressed by Prospero and also tortured by him. He has no dignity in his birthplace. Caliban in Hag-Seed is not only the character Caliban, but signifies all the crimes in the prison. They cooperate with Prospero(Felix) to fight with the power class for their rights.

The play showed in Hag-Seed revealed the defiance of the marginalized class, by rewriting the displacement of power, Atwood retold the power in the background of modern society. In Hag-Seed, there is an important image that is "prison". The Fletcher Correctional is a fictional institution but it does exist in the novel. However, the "prison" has other meanings in The Tempest. It refers to the tree that trapped Ariel, the magic that bounded Prospero, and the hole that imprisoned Caliban. The trapped people not only the inmates but also the character's in The Tempest want to get rid of the "prison" so they treat the power in different ways to struggle for freedom. On the one hand, the rivalry in The Tempest of the power on the island is between Prospero and Caliban or Ariel, while in Hag-Seed, it places between the low class and the powerful class. The island in Shakespeare's play is a land of exile to Prospero while to Sycorax and Caliban, the island is their home, their place. Prospero as a character with overwhelming magic power on the island is harsh to his slaves. He enslaves Caliban representing the inequality of power which makes inequality between people. Besides, Ariel on the island is also a native fairy. She was trapped in the wood by Sycorax and was released by Prospero. However, Prospero takes himself as a liberator so he enslaves Ariel to do everything for him until he gives Ariel freedom. Prospero said to Ariel that: "If thou more murmur'st, I will rend an oak, And peg thee in his knotty entrails, till Thou hast howled away twelve winters".(1.2 line, p.295) He treats the dull thing Caliban without any sympathy, "If 
thou neglect'st, or dost unwillingly What I command, I'll rack thee with old cramps, Fill all thy bones with aches, make thee roar, That beasts shall tremble at thy din". (1.2 line,p.369) The inequality of power always brings oppression. Not only Caliban but also Ariel, all want to break the limitations made by Prospero. Hegel demonstrates the contradictory and interdependent relationship between the self and the other through the "Master/Slave" dialectic. The Master, as the subject, is powerful to the Slave who can force him to work and deprive his free will. The Slave knows he is a Slave because he is recognized by the Master so he has to give up his subjectivity and work for the Master to meet his needs. (Hegel, 2016, p.42) Therefore, as "the other" on the island, Caliban and Ariel are doomed to be in an oppressed place.

On the other hand, Atwood sets the position in a prison in Hag-Seed. She chooses to subvert the initial representation of the link between colonization and other. In her retold story, Caliban becomes the collective prisoner. By translating Caliban's native status to the Fletcher player's inmate, Atwood tries to make the social commentary about the way the people treat the justice system and incarcerated men. In this novel, Felix as a famous director performed several plays in the prison. He is "Prospero" in the play The Tempest acted by the crimes also he is an avenger in the whole play. The crimes in the prison are a group of marginalized people in society, they are abandoned and despised by other common people. In the ruler class's eyes, "Prisons are for incarceration and punishment, not for spurious attempts to educate those who cannot, by their natures, be educated." (Atwood,p.299) This is the prejudice of ruler class to the subaltern. However, the inmates in the prison are also excellent people. Like 8Handz played Ariel in this play is good at computer. He is behind the folding screen that hides the computer screen, the control panel, the central microphone, and the two sets of headphones. He sits there to control the "storm" in the play and he finishes it perfectly. He is a kind person always ready to help poor people, but he was betrayed by his partner in a task. Leggs, the player of Caliban, is a veteran who was diagnosed with PTSD. He is convicted on charges of break-and-enter and assault. Leggs chooses to act Caliban because he admires the courage and candidness in him who keeps resisting injustice. Many inmates have traumatic experiences in the prison. They are the people who were ignored by the public. Besides, they belong to the low class in society and they belong to "the other" in the mainstream people. While Felix helps the group of "the other" to fight with their rights. Atwood wants to express a point in this novel that is: drama is a powerful tool for education. That is, the prisoners can be normal people if they have a second chance. Lonnie says in this novel: If I were redesigning the prison system, I'd try giving the inmates more freedom, not less. They could vote on things, they could make their own decisions. Design their menus, for instance; that could be a useful skill they could develop"(p.301). These words give more rights and freedom to marginalized people. They can contribute to society if people give them hope and care for them sincerely. At the end of the play, Prospero's forgiveness of Caliban's sins as an integral part of his self-growth could reflect the importance of society's ability to treat others who have done the world wrong with mercy and kindness, as to end the vicious cycle of the other. Furthermore, Atwood here challenges Shakespeare and presents an alternative view that we are all, in some way or another, this deeply othered and isolated character.

This is the main point that Atwood wants to express. She wants to question the power relation in the classic works to help the group of "the other" placed in the marginalized position to move to the center and change their subaltern place with humanity. This novel also expressed her desire to help the 
lower class gain their rights and voice and criticize the corruption among the ruler class.

\section{The Rewriting of New Women in Hag-Seed}

Female images have changed in Atwood's novel. In The Tempest, the female character Sycorax is described as a foul witch and Miranda is a docile girl who always obeys her father. While Miranda in Hag-seed becomes "a motivator of action rather than a receiver of patriarchal power". Rather than the limited power, she has in the original text, the spirit of Miranda becomes Felix's motivation to continue with his production against all the odds. Take the character, Miranda, as an example, in Hag-Seed, the spirit of Miranda has power over Felix in an almost symbiotic relationship which is very different from the powerlessness she has as the flesh daughter in The Tempest. In the play, she embodies the extension of Prospero's authority but only if, by remaining a virgin, she serves as a suitable bride for the husband of his choice.

Women in The Tempest were seen as objects of their fathers or husbands during Shakespeare's time. This meant that they were inferior to men and do not have any rights. In the play, there is no woman on stage aside from the goddesses in Prospero's masque and Miranda. This play highlights how men ignore woman's needs and their importance. The man at that time only value women who are "innocent and pure", as Gonzalo states. The female character in The Tempest is "the other". Unlike Shakespeare's time, women in modern western society have more rights. They are viewed as individual beings instead of man's attachments. Atwood's female characters are more empowered, knowledgeable, and strong. We can see this with Miranda. Atwood's Miranda is much more powerful and knowledgeable. Atwood entwines a plot that largely relies on Miranda to progress. Without her, Felix would never have had the desire to put on a production of The Tempest. Not only Felix's daughter Miranda but also the actress Anne-Marie. Anne-Marie is the only one that goes into the prison. She undertakes social pressure and lives a hard life with a pessimistic attitude. While the play The Tempest gives her hope. After participating in the play, she shows her talented and enthusiastic energy in choreography, dance, and acting. She brings her expertise to the production. Besides, she creates a sense of security for Felix as he creates the perfect illusion. She does Felix a great favor and helps him complete the revenge perfectly. Miranda, Anne-Marie, and Estelle are independent female characters and even have a great influence on a man's fortune. Besides, the description of Sycorax is also a point that representing Atwood's praise for women. In Hag-Seed, the foul witch Sycorax “must've loved him enough to at least not drown him like a kitten. She did the bare essentials, she kept him alive. You gotta hand it to her, considering. She was all alone on the island, birthing the baby and so forth. She maybe has her failings, but she did what she could for him. She was tough."(p.382) Atwood described Sycorax with humanistic views that are different from the original one in The Tempest. The images of women in Hag-Seed changed a lot. Female characters in Atwood's adaptation get rid of the label "the other".

Atwood has demonstrated through her novels that she privileges compassion, empathy, and humanity. Many of her novels are about fighting for human rights. She states in an interview when discussing The Tempest:

"The Tempest has that wonderful hinge moment in which Ariel, who is not a human being, says 
to Prospero, 'These people that you've enchanted are suffering, and they make me feel very sad, and my affections are moved and so should yours be.' And Prospero says, 'Oh, really.' And Ariel says, 'Mine would, sir, were I human.' So, what is it to be human? What is it to be human? According to Ariel, to be human is to have empathy; among other things. And without empathy, there are no human rights..."

Atwood tries to demonstrate that "the other" needs a chance to experience humanistic concerns which will help them get over their loneliness and selfishness. Not only the marginalized group but also the female characters. And she insists that humanity will not that difficult to get if everyone is willing to give a second chance to "the other".

\section{Conclusion}

This paper has analyzed the marginalized people and the female characters in Hag-Seed. The name of the book Hag-Seed is a kind of respect for The Tempest written by Shakespeare. She uses this signifier to symbolize the marginalized people or "the others" in modern society. Atwood in this novel describes the indifferent world and aims to fix it. When she began to focus on the books that dealt with literature and drama being taught or being experienced within prisons, she decided to make connections between the classic and the contemporary realities. The group of the subaltern is one of her aims to rewrite in this novel. The people who were discriminated against are lonely and helpless, what they need are people's forgiveness and kindness. The lower classes like the inmates and part of the female characters are deprived of the right to speech, which is the essence of the humanistic spirits. In the novel, through the revenge play in prison, Felix and the crimes can escape hopelessness and acquire the right to speak freely and Anne-Marie also gets her lover and bright future.

In conclusion, Atwood found the problems in society and she tries to change them by using literary works. The ideal society imagined by Atwood is a place where there is no prejudice, hierarchy, discrimination, and full of humanity. She desires to build a harmonious society with love and kindness. The prisoner's successful revolt symbolizes the increasing awareness of subaltern's rights, reflecting Atwood's concern for the marginalized people.

\section{Notes}

112See "Hogarth Shakespeare" $<$ http://hogarthshakespeare.com/hag-seed/>

344See "A Perfect Storm: Margaret Atwood on Rewriting Shakespeare's

Tempest" $<$ https://www.theguardian.com/books/2016/sep/24/margaret-atwood-rewriting-shakespeare-te mpest-hagseed\#maincontent $>2016-9-24$

\section{References:}

[1]. Atwood, Margaret. (2016). Hag-Seed. London: Hogarth Press.

[2]. Atwood, Margaret. (2002). Negotiating with the Dead: A Writer on Writing. New York: Anchor.

[3]. Abrams, Rebecca. (2016). Hag-Seed by Margaret Atwood Review-The Tempest Retold. Financial Times.

[4]. Hegel, G.V.F. (2016).The Phenomenology of Mind. Createspace Independent Publishing. 
[5]. Jayendran, Nishevita. (2020). 'Set Me Free': Spaces and the Politics of Creativity in Margaret Atwood's Hag-Seed. Journal of Language, Literature and Culture,

[6]. Percec, Dana. (2018).The Canada Tempest Margaret Atwood and Shakespeare Retold as Hag-Seed. Caietele Echinox.

[7]. St. John Mandel, Emily. (2016). Margaret Atwood Meets Shakespeare in a Retelling of 'The Tempest'. The New York Times.

[8]. Ward, Sophie, Connolly, Roy. (2018). The play is a prison: the discourse of Prison Shakespeare. Studies in Theatre and Performance. 